\title{
Hydatid cyst of the thigh: a challenging diagnosis
}

\author{
Manel Landolsi, ${ }^{1}$ Sami Kouki, ${ }^{2}$ Achraf Abdennadher ${ }^{3}$
}

${ }^{1}$ Radiology, Faculty of Medicine, University of Tunis El Manar, Tunis, Tunisia

${ }^{2}$ Medicine Faculty of Tunis, Radès, Tunisia

${ }^{3}$ Department of Orthopedics, Military Hospital of Tunisia, Tunis, Tunisia

\section{Correspondence to}

Dr Manel Landolsi,

landolsimanel@yahoo.fr

Accepted 12 September 2017

\section{DESCRIPTION}

Hydatid disease is a common infection in Mediterranean countries. It is caused by a parasite 'Echinococcus granulosus', which may affect several organs. Liver and lungs are frequent locations. Primary hydatid cyst located in the musculoskeletal system is uncommon.

These images illustrate the case of a 27-year-old man without past medical history who presented with a swelling of the right thigh that appeared 6 months ago. Physical examination showed a tender mass of the upper third of the right thigh. There was no history of trauma or fever. Inflammatory blood markers were normal. Ultrasonography was first performed revealing a huge multilocular intramuscular cystic mass of the thigh without tissue components or calcifications. The aspect was suspicious of a cystic lymphangioma. An MRI of the thigh was performed to evaluate accurately the size of the mass and its location. It revealed a voluminous mass of $10 \times 6 \mathrm{~cm}$ developed in the medial compartment of the upper thigh. This mass was hypointense on T1-weighted sequences and hyperintense on T2-weighted images with peripheral enhancement after contrast material injection (figures 1 and 2). The presence of small cysts inside the mass was highly suspicious of hydatid cyst. Chest X-ray and abdominal ultrasound did not reveal visceral location. Serological test ELISA was negative. Surgical excision of the mass confirmed the diagnosis of hydatid cyst. It showed daughter cysts in the cut section (figure 3). Histopathological examination confirmed the diagnosis.

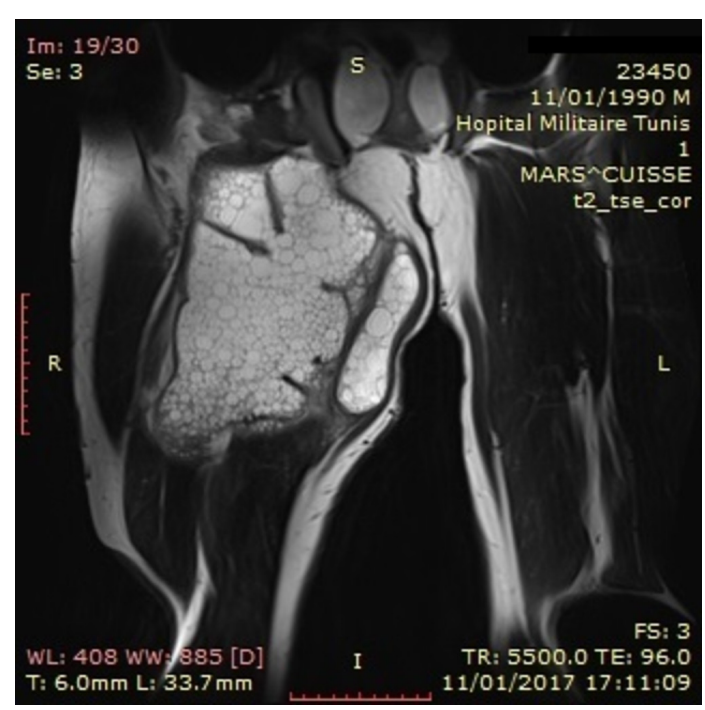

Figure 1 Coronal T2-weighted image showing a cystic mass of the thigh with vesicular content.

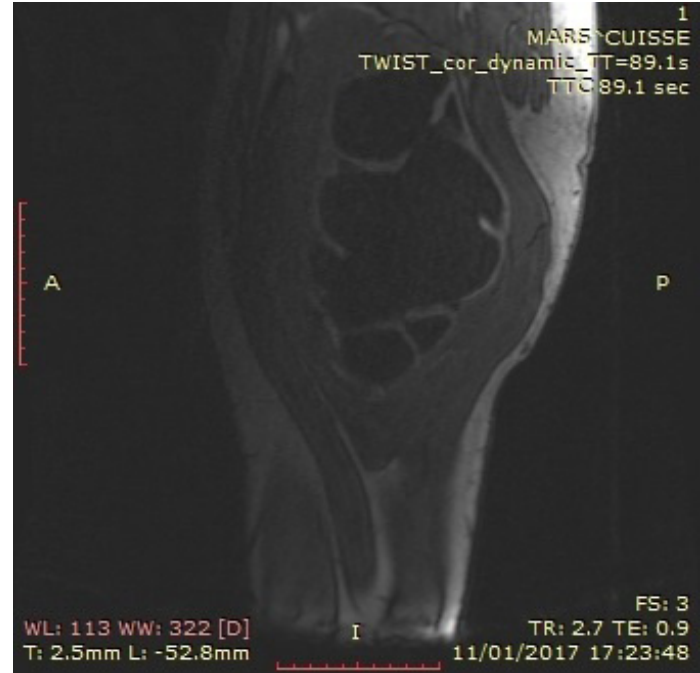

Figure 2 Sagittal T1-weighted image after contrast material injection showing a cystic mass of the thigh with peripheral enhanced rim.

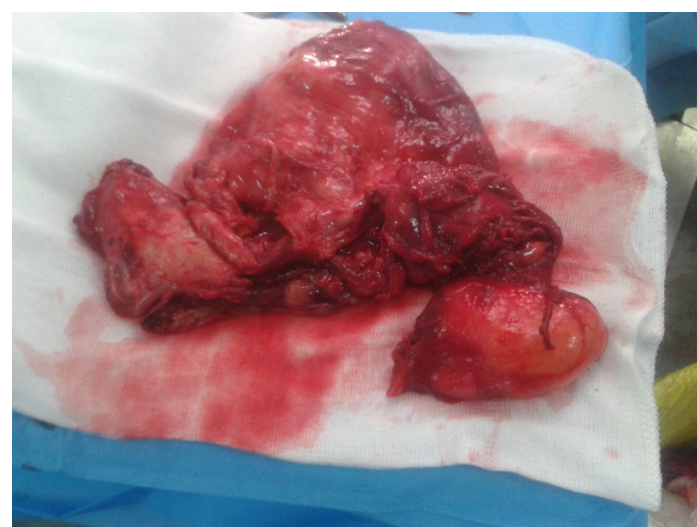

Figure 3 Macroscopic view of the tumour showing a cystic content.

Learning points

- Primary hydatid cyst located in the musculoskeletal system is uncommon with innocuous clinical presentation.

- The diagnosis is suspected in case of cystic mass with vesicular fibrils.

- An MRI is advised to assess the exact location of the cyst and to identify the involved muscles. It also helps eliminating differential diagnosis such as haematoma, cystic lymphangioma or tumour. It typically shows a cystic vesicular mass with peripheral hypointense rim.

- Total excision of the mass is recommended as a curative treatment. 
Total excision of the mass is recommended as a curative treatment. The rupture of the cyst should be avoided because of high risk of anaphylactic reaction due to leakage of daughter cysts. ${ }^{2}$ In case of incomplete excision of the cyst, additional chemotherapy is needed.

Contributors The corresponding author (ML) wrote the manuscript. The co-author (SK) contributed to the writing of the manuscript and the literature review. The co-author (AA) collected the patient data and described the surgical findings.

Competing interests None declared.

Patient consent Obtained.

Provenance and peer review Not commissioned; externally peer reviewed.
(C) BMJ Publishing Group Ltd (unless otherwise stated in the text of the article) 2017. All rights reserved. No commercial use is permitted unless otherwise expressly granted.

\section{REFERENCES}

1 Kazmi Z, Qureishi S, Quraishy MS, et al. Atypical presentation of hydatid cyst in the thigh. J Coll Physicians Surg Pak 2017:27:51-2.

2 Gupta A, Singal RP, Gupta S, et al. Hydatid cyst of thigh diagnosed on ultrasonography - a rare case report. J Med Life 2012;5:196-7.

3 Argy N, Abou Bacar A, Boeri C, et al. Primary musculoskeletal hydatid cyst of the thigh: Diagnostic and curative challenge for an unusual localization. Can I Infect Dis Med Microbiol 2013;24:e99-101.

Copyright 2017 BMJ Publishing Group. All rights reserved. For permission to reuse any of this content visit

http://group.bmj.com/group/rights-licensing/permissions.

BMJ Case Report Fellows may re-use this article for personal use and teaching without any further permission.

Become a Fellow of BMJ Case Reports today and you can:

- Submit as many cases as you like

- Enjoy fast sympathetic peer review and rapid publication of accepted articles

Access all the published articles

Re-use any of the published material for personal use and teaching without further permission

For information on Institutional Fellowships contact consortiasales@bmjgroup.com

Visit casereports.bmj.com for more articles like this and to become a Fellow 